\title{
Evaluation of a Sensitive Copeptin Assay for Clinical Measurement
}

\author{
D. Terzic ${ }^{1}$, A. S. Johansson-Fällgren ${ }^{2}$, O. Ragnarsson ${ }^{3}$, J. P. Goetze ${ }^{1}$ and O. Hammarsten ${ }^{2, *}$
}

${ }^{1}$ Department of Clinical Biochemistry, Rigshospitalet, University of Copenhagen, Blegdamsvej 9, DK 2100 Copenhagen, Denmark

${ }^{2}$ Department of Clinical Chemistry and Transfusion Medicine, Sahlgrenska University Hospital at Sahlgrenska Academy, University of Gothenburg, S-413 45 Goteborg, Sweden

${ }^{3}$ Section for Endocrinology, Sahlgrenska University Hospital at Sahlgrenska Academy, University of Gothenburg, S-413 45 Goteborg, Sweden

\begin{abstract}
Background: Copeptin, a marker of vasopressin production, has been introduced for earlier diagnosis of acute myocardial infarction and other clinical emergencies. We evaluated the analytical performance of a new generation copeptin assay in an inter-laboratory trial.

Methods: Precision, linearity range, carry-over contamination, the limit of blank and an inter-laboratory comparison trial for the copeptin US KRYPTOR assay were performed on the B $\cdot \mathrm{R} \cdot \mathrm{A} \cdot \mathrm{H} \cdot \mathrm{M} \cdot \mathrm{S}$ KRYPTOR compact PLUS.

Results: The intra-assay imprecision (CVs) was $12.6-2.2 \%$ and total imprecision over five days was $12.3-4.3 \%$ between 3.1 and $18.2 \mathrm{pmol} / \mathrm{L}$. The assay had excellent linearity between 7-222 pmol/L. The limit of blank was $2.5 \mathrm{pmol} / \mathrm{L}$ and the limit of detection was $3.2 \mathrm{pmol} / \mathrm{L}$, but was dependent on the analyte-free material used. No significant difference between sample type, such as serum or different types of plasma or reagent lots, was noted. The copeptin results remained unchanged upon five repeated freeze-thaw cycles. A set of patient samples with a mean copeptin concentration of 2.1-61 $\mathrm{pmol} / \mathrm{L}$ run at two separate sites showed close correlation $\left(\mathrm{r}^{2}=0.99\right.$, slope $=1.01$, intercept $\left.=0.35\right)$, indicating comparable results across laboratories.
\end{abstract}

Conclusion: The new ultrasensitive copeptin KRYPTOR assay shows excellent inter-lab precision, opening up the possibility for international guidelines to exclude acute myocardial infarction.

Keywords: Copeptin, diabetes insipidus, myocardial infarction, heart failure, vasopressin.

\section{INTRODUCTION}

Vasopressin (also known as antidiuretic hormone $(\mathrm{ADH})$ ) has been inaccessible to routine measurements due to its extreme instability in plasma. Copeptin is a stable, apparently non-functional, 39 amino acid peptide that is cosecreted with vasopressin, both being produced by cleavage of the vasopressin precursor $[1,2]$. The development of automated copeptin methods now allows for measurement of the release of vasopressin in different disease states [3]. The most direct application for copeptin measurement is in the diagnosis of central diabetes insipidus, a disease caused by a primary vasopressin synthesis defect [4]. Measurement of copeptin has also been suggested in the early exclusion of acute myocardial infarction among patients with suspected acute coronary syndrome $[5,6,10]$. In addition, copeptin measurement provides prognostic information in several acute conditions such as myocardial infarction [11], heart failure [12-16], infection [17-19], stroke [20,21], traumatic

*Address correspondence to this author at the Department of Clinical Chemistry and Transfusion Medicine, Bruna stråket 16, Sahlgrenska Academy at the University of Gothenburg, SE-41345 Gothenburg, Sweden;

Tel: +46-31-342 1561, 342 9941; +46-733-200834; Fax:+46-31-82 84 58; E-mail: ola.hammarsten@clinchem.gu.se brain injury [22,23], and acute exacerbation of chronic obstructive pulmonary disease [24].

The introduction of copeptin measurements in clinical routine practice requires that the methods used are validated and show appropriate precision, analyte stability, sensitivity and inter-laboratory variation. A newly developed copeptin assay with improved analytical sensitivity has been designed to meet the analytical specifications necessary to enhance the current use of copeptin in clinical practice. Independent analytical validation is, however, essential for the safe introduction of copeptin measurements in the clinical setting and for future international guidelines on the diagnosis of diabetes insipidus and exclusion of acute myocardial infarction. Thus, the purpose of this study was to validate the analytical performance of the copeptin ultrasensitive method run on the KRYPTOR compact PLUS in an inter-laboratory international evaluation.

\section{MATERIALS AND METHODES}

\section{Study Population}

Blood samples from healthy volunteers $(\mathrm{n}=13,6$ men and 7 women, age ranging from 25 to 48 years) with no history 
of disease and not receiving medical treatment were collected from employees at the Department of Clinical Biochemistry, Rigshospitalet, Copenhagen, Denmark. All the serum and plasma samples (EDTA, heparin) were drawn by standard venipuncture using a butterfly needle $(21 \mathrm{G})$. The samples were centrifuged within $30 \mathrm{~min}$. at $2000 \mathrm{~g}$ for 10 min., transferred to cryotubes and frozen in aliquots at $-80^{\circ} \mathrm{C}$ until analysis. Decoded serum samples with different copeptin concentrations for the inter-laboratory comparison (Fig. 3) were collected from analytical routine work at Sahlgrenska University Hospital, based on NT-proBNP results. Serum samples from patients with apparent complete central diabetes insipidus were collected during follow-up visits at the Department of Endocrinology at Sahlgrenska University Hospital, Gothenburg, Sweden. Samples were stored at $20^{\circ} \mathrm{C}$ until analysis. The study was approved by the ethics committee at the University of Gothenburg and the study protocol followed the ethical guidelines of the 1975 Declaration of Helsinki.

\section{Diabetes Insipidus Patients}

Patient 1 was a 58-year-old man who was diagnosed with large non-functioning pituitary adenoma eleven years earlier. Magnetic resonance imaging showed a large intra- and supra-sellar tumor, compressing the optic chiasm. Pituitary surgery with transcranial approach was performed. Postoperatively, the patient developed panhypopituitarism, including central diabetes insipidus (DI), and has been receiving replacement therapy with hydrocortisone, L-Thyroxin, testosterone, growth hormone and desmopressin ever since. Patient 2 was a 49-year-old woman who was operated on transsphenoidally one year earlier due to ACTH-producing pituitary adenoma (Cushing's disease). Histopathological examination confirmed the diagnosis and also showed parts of a normal posterior pituitary. Postoperatively, she developed hypernatremia, polyuria ( $\sim 8$ liter per day) and dilute urine. Initially, she received conservative treatment with increased fluid intake. Two weeks later, when still producing large amounts of dilute urine, she was given desmospressin with prompt effect. Based on the histopathological diagnosis, the clinical picture and treatment effect, the patient was diagnosed with central diabetes insipidus and was still receiving desmopressin at the time of participation in this study.

\section{Limit of Blank and Assay Linearity}

Sample handling, analysis and calibrations were performed according to the manufacturer's instructions. All reagents, calibrators and controls used were provided by B.R.A.H.M.S. The limit of blank (LoB) was determined using the horse serum-based diluent provided with the assay. Horse serum was analyzed 22 times in a single run (Table 1) and the 95th percentile from these measurements was calculated. A patient serum sample $(3.0 \mathrm{pmol} / \mathrm{L}$, Table 1) that gave a significantly $(p<0.05)$ higher value than the LoB (low sample) was analyzed 12 times and used to calculate the limit of detection (LoD). Calculations of $\mathrm{LoB}$ and $\mathrm{LoD}$ were performed according to the CLSI EP17-A specifications ( $\mathrm{LoB}=$ meananalyte-free $+1.645 \mathrm{SD}_{\text {analyte-free }}$ and $\mathrm{LoD}=\mathrm{LoB}+-$ $1.645 \mathrm{SD}_{\text {low sample }}$. In addition, $5 \%$ human albumin solution (50g albumin/L in water) for in vivo infusion (CSL Behring, King of Prussia, USA) ( $\mathrm{n}=3$ ), pig plasma from three individual pigs and serum samples from two patients with apparent complete central diabetes insipidus were analyzed. The diabetes insipidus patient samples were also diluted 1:3 with diluent and analyzed $(n=4)$. Dilution linearity was evaluated by duplicate analysis of two-fold dilutions of a patient serum sample with a mean copeptin concentration of $222 \mathrm{pmol} / \mathrm{L}$ and a serum sample with a mean copeptin concentration of $3.0 \mathrm{pmol} / \mathrm{L}$, resulting in calculated copeptin concentrations between 7-222 $\mathrm{pmol} / \mathrm{L}$.

\section{Imprecision Study}

Serum or EDTA plasma samples (mean copeptin concentration 1.4-102 $\mathrm{pmol} / \mathrm{L}$ ) were used to determine the intra-

Table 1. Intra-assay Imprecision of the Copeptin US KRYPTOR Assay

\begin{tabular}{|c|c|c|c|}
\hline Sample Type & Mean Copeptin (pmol/L) & CV(\%) & 18.3 \\
\hline \hline EDTA plasma & 1.4 & 21.6 & 10 \\
\hline EDTA plasma & 1.8 & 17.5 & 22 \\
\hline Horse serum & 1.9 & 14.8 & 12 \\
\hline serum & 3.0 & 18.0 & 10 \\
\hline EDTA plasma & 3.0 & 15.6 & 10 \\
\hline serum & 3.1 & 8.3 & 10 \\
\hline Serum & 5.0 & 6.3 & 10 \\
\hline EDTA plasma & 7.9 & 6.8 & 12 \\
\hline serum & 9.3 & 2.2 & 12 \\
\hline serum & 18.2 & 1.2 & 10 \\
\hline
\end{tabular}


assay precision by replicate measurements $(n=10-12)$ in a single run. Total five-day imprecision was evaluated by analyzing aliquots of three serum samples (mean copeptin concentration 3.0, 18 and $103 \mathrm{pmol} / \mathrm{L}$ ) with twelve replicates on day one and three replicates on day 2-5 ( $\mathrm{n}=24$ determinations). Aliquots were stored frozen $\left(-20{ }^{\circ} \mathrm{C}\right)$ and thawed immediately before analysis (Table 1).

\section{Inter-laboratory Survey}

Two laboratories participated in the inter-laboratory comparison survey. Five unique frozen $\left(-20^{\circ} \mathrm{C}\right)$ serum samples from 18 individual patients (mean copeptin concentration range $2.1-61 \mathrm{pmol} / \mathrm{L}$ ) were transported on dry ice to the testing laboratories and copeptin concentrations were measured in a single run on the same day at the two sites.

\section{Stability}

To analyze whether freeze-thaw cycles affect the copeptin concentrations, three EDTA plasma samples with copeptin concentrations of $8-13 \mathrm{pmol} / \mathrm{L}$, determined on the unfrozen samples, were split into five aliquots. The aliquots were frozen and thawed repeatedly up to five times at $-80^{\circ} \mathrm{C}$. All the samples were later analyzed in a single run.

\section{Carry-over Analysis}

Inter-sample contamination (carry-over) by the KRYPTOR compact PLUS was determined by three replicate measurements of a low serum sample (mean copeptin concentration $3.1 \mathrm{pmol} / \mathrm{L}$ ) after analysis of a high serum sample (mean copeptin concentration $225 \mathrm{pmol} / \mathrm{L}$ ). The analysis was repeated twice.

\section{RESULTS}

The results of the imprecision study are summarized in Table 1, Table 2 and Fig. (1). The intra-assay coefficient of variation $(\mathrm{CV})$ ranged from $17.5 \%-22 \%$ for samples below 3

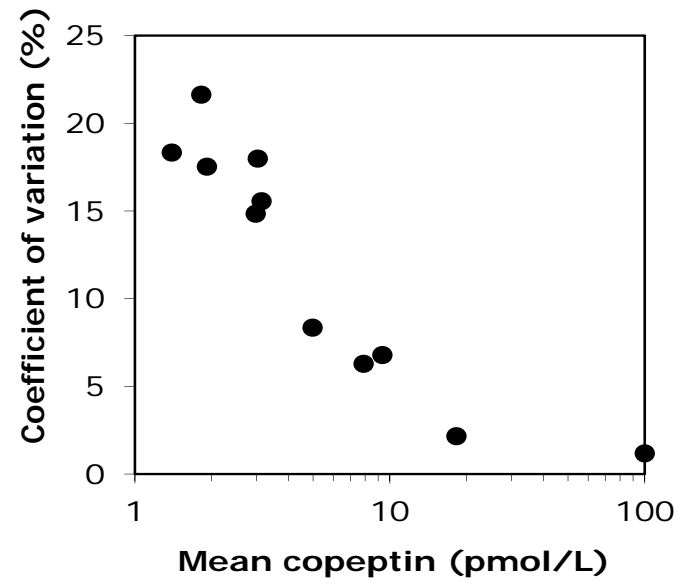

Fig. (1). Intra-assay imprecision of the copeptin US KRYPTOR assay. Patient serum or EDTA plasma samples with mean copeptin concentrations between $1.3-102 \mathrm{pmol} / \mathrm{L}$ were analyzed 10-22 times to determine the concentration-dependent intra-assay $\mathrm{CV}$.

$\mathrm{pmol} / \mathrm{L}$ and $1-2 \%$ for samples with copeptin concentrations above $10 \mathrm{pmol} / \mathrm{L}$ (Table 1). The intra-assay $\mathrm{CV}$ increased when the copeptin concentration was below10 pmol/L (Fig. 1), but the CV remained below $10 \%$ down to $5 \mathrm{pmol} / \mathrm{L}$. Total five-day imprecision was close to the intra-assay imprecision (Table 2). Repeated serial analysis of samples with a 75-fold difference in copeptin concentration did not show any evidence of cross-contamination (Table 3 ). Dilution of a high patient sample $(222 \mathrm{pmol} / \mathrm{L})$ with a low patient sample (3.0 pmol/L) resulted in excellent linearity between 7-222 $\mathrm{pmol} / \mathrm{L}$ (Fig. 2). In addition, analysis of individual patient samples with a range of copeptin concentrations (2.1-61 $\mathrm{pmol} / \mathrm{L})$ at two different laboratories showed close correlation (Fig. 3). Repeated freeze-thaw cycles did not result in significant changes to the measured copeptin concentrations (Table 4). In addition, measurement of the copeptin concentration in serum, heparin or EDTA plasma collected from 13

Table 2. Imprecision of the Copeptin US KRYPTOR Assay

\begin{tabular}{|c|c|c|c|}
\hline Measurement & Sample 1 & Sample 2 & Sample 3 \\
\hline \hline Mean Copeptin (pmol/L) & 3.1 & 17.9 & 103 \\
\hline Intra-assay imprecision (CV\%) & 12.6 & 2.3 & 1.2 \\
\hline Total five-day imprecision (CV\%) & 12.3 & 4.1 & 2.5 \\
\hline Largest difference between series (pmol/L) & 0.42 & 1.8 & 24 \\
\hline
\end{tabular}

Table 3. Analysis of Carry-over Contamination

\begin{tabular}{|c|c|}
\hline Sample & Mean Copeptin Concentration (pmol/L) \\
\hline \hline Uncontaminated Low sample & 3.1 \\
\hline High sample & 225 \\
\hline Low sample after high sample, run 1 & 2.5 \\
\hline Low sample after high sample, run 2 & 3 \\
\hline 3 & 3 \\
\hline
\end{tabular}




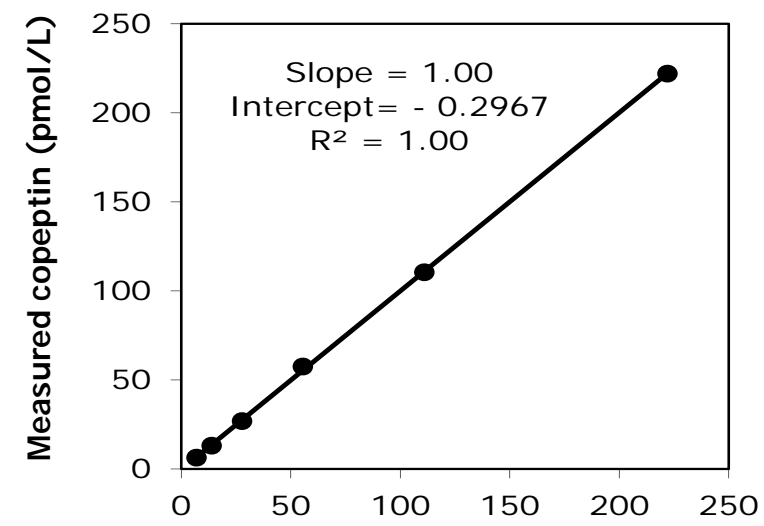

Calculated copeptin ( pmol/ L)

Fig. (2). Linearity analasys of the copeptin US KRYPTOR assay. Dilution of a high patient serum sample $(222 \mathrm{pmol} / \mathrm{L})$ with a low patient serum sample $(3.0 \mathrm{pmol} / \mathrm{L})$, resulting in a concentration range between 7-222 pmol/L, was analyzed. Plotted data are means of duplicate measurements. Error bars are too small to be visualized.

apparently healthy individuals did not reveal any significant difference linked to sample type (Table 5). The LoB was 2.5 $\mathrm{pmol} / \mathrm{L}$ and the LoD $3.2 \mathrm{pmol} / \mathrm{L}$. However, the signal dif- fered significantly if the same apparently copeptin-free sample was reanalyzed on a different day and when other types of apparently copeptin-free samples were analyzed (Table 6).

\section{DISCUSSION}

Copeptin measurement holds great promise as a marker of poor prognosis in several acute conditions, in the diagnosis of diabets insipidus [4] and in early rule-out of acute myocardial infarction [5,7]. However, several studies have used copeptin assays with an unacceptable analytical precision at the proposed cut-off values [5,9]. On the other hand, studies using more sensitive copeptin assays lack rigorous standardization and are unsuitable in the clinical setting $[7,8]$. This may have contributed to the variability of reported cut-off values. In response to the clinical emphasis on low copeptin concentrations and the need for optimum analytical performance, manufacturers have produced a copeptin US assay with improved precision and sensitivity, capable of measuring copeptin concentrations in healthy individuals. For this reason, we have evaluated the analytical performance of a new improved copeptin assay on the KRYPTOR compact PLUS platform from Brahms. Multicenter evaluations are an important part of the analytical and clinical validation process, as they often reveal how an assay will perform realistically in daily practice.

Table 4. Copeptin Measurements in Serum Samples After Repeated Freeze-thaw Cycles (pmol/L)

\begin{tabular}{|c|c|c|c|c|c|}
\hline Patient No. & Frozen 1 Time & Frozen 2 Times & Frozen 3 Times & Frozen 4 Times & Frozen 5 Times \\
\hline \hline 3 & 13.1 & 13.1 & 13.3 & 13.0 & 12.3 \\
\hline 9 & 11.0 & 10.8 & 11.2 & 11.6 & 8.5 \\
\hline 12 & 8.1 & 9.2 & 8.6 & 9.4 \\
\hline
\end{tabular}

Table 5. Copeptin Measurements in Serum, EDTA or Heparin Plasma (pmol/L)

\begin{tabular}{|c|c|c|c|c|c|}
\hline Patient nr. & Sex & Age & Serum & EDTA Plasma & Heparin Plasma \\
\hline 1 & female & 25 & 1.5 & 1.1 & 1.9 \\
\hline 3 & male & 39 & 12.0 & 12.0 & 13.0 \\
\hline 4 & male & 36 & 3.2 & 3.6 & 4.0 \\
\hline 6 & male & 25 & 3.1 & 3.1 & 2.9 \\
\hline 7 & female & 28 & 4.1 & 3.9 & 3.7 \\
\hline 8 & male & 37 & 1.6 & 2.5 & 2.5 \\
\hline 12 & female & 29 & 7.7 & 7.5 & 7.7 \\
\hline 13 & female & 34 & LOW & 1.0 & 1.2 \\
\hline
\end{tabular}




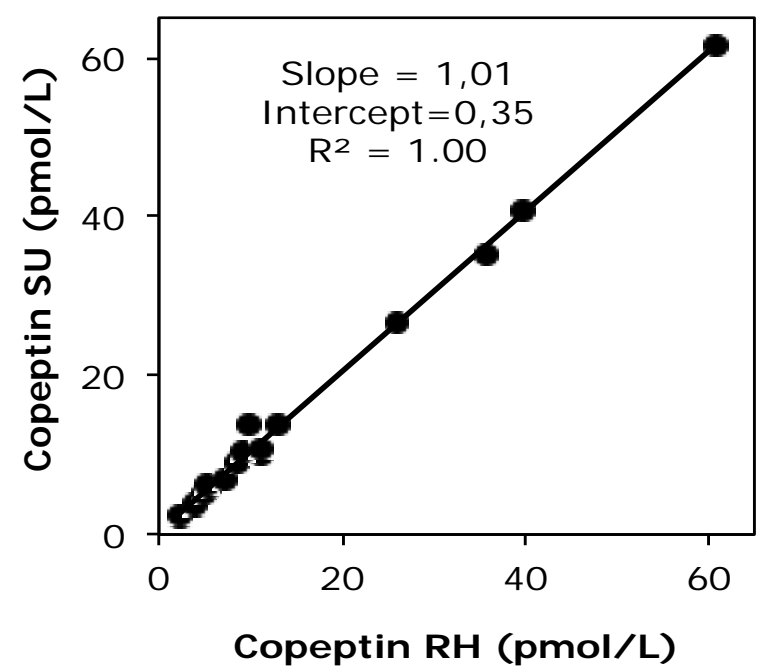

Fig. (3). Inter-laboratory evaluation of the copeptin US KRYPTOR assay. Aliquots of individual patient serum samples with a mean copeptin concentration between 2.1-61 pmol/L were analyzed in the same run at Sahlgrenska University Hospital, Sweden (SU), and Rikshopsitalet (RH), Denmark.

The diagnosis of myocardial infarction often relies on baseline serum concentrations and the dynamic response of the myocardial necrosis markers troponin $\mathrm{T}$ or troponin $\mathrm{I}$. Analytical guidelines recommend an optimum CV for troponin of $\leq 10 \%$ at the decision limit [25]. Recently, a low copeptin concentration a few hours after symptom onset has been shown to be useful in the early exclusion of myocardial infarction $[5,7,8]$. Unfortunately, most studies have used clinical assays unable to measure copeptin concentrations below $14 \mathrm{pmol} / \mathrm{L}$ with sufficient precision and have therefore been forced to set the cut-off points at the analytical imprecision limit [5,9]. Using a more sensitive research-based sandwich immunoluminometric assay, the median copeptin level was $3.7-4.2 \mathrm{pmol} / \mathrm{L}[1,8]$ and the 95 th copeptin percentile was $9.8 \mathrm{pmol} / \mathrm{L}$ in the general population [7]. This indicates that copeptin assays capable of reliably measuring below $10 \mathrm{pmol} / \mathrm{L}$ may be required to define optimum cut-off points. In addition, to allow for the development of international guidelines, there is a need for copeptin assays that are fast and robust enough to enable clinical measurements with low inter-lab variation. The present performance data for the copeptin US KRYPTOR assay indicate that this method meets these criteria. The CV was $<10 \%$ at $5 \mathrm{pmol} / \mathrm{L}$ and showed good inter-laboratory precision when actual patient samples over a wide range of copeptin concentrations were used. Furthremore, the assay was not significantly affected by common pre-analytical errors such as storage [2], freezethaw cycles and sample type. However, the analytical sensitivity was not found to match the information provided by the manufacturer. The assay insert gives the LoD as 0.9 $\mathrm{pmol} / \mathrm{L}$, the functional sensitivity with a $\mathrm{CV}<20 \%$ as 2 $\mathrm{pmol} / \mathrm{L}$ and the limit of quantification as $1.9 \mathrm{pmol} / \mathrm{L}$. Our results do not confirm these values. Use of several apparently analyte-free preparations, including the diluent provided with the assay kit, resulted in values around 1-2 $\mathrm{pmol} / \mathrm{L}$ (Table 6) and a LoB of $2.5 \mathrm{pmol} / \mathrm{L}$. Although the $\mathrm{CVs}$ of these measurements were $<20 \%$, our data indicate that the signal is likely due to an analyte-independent background signal. Since the KRYPTOR Compact PLUS is unable to measure in plain buffers, we cannot exclude the possibility of matrix effects or of copeptin-like molecules being present in the apparent analyte-free solutions that we used. However, due to this background signal, the limit of quantification (LoQ) must be in the range of 3-5 pmol/L. This introduces an analytical limit to the applicability of the copeptin US KRYPTOR assay in the diagnosis of diabetes insipidus, where the suggested diagnostic test is based on a relative increase in copeptin during a water deprivation test. As most patients undergoing this test had a baseline copeptin level $<3.2 \mathrm{pmol} / \mathrm{L}$ [4] in agreement with the reference linits among healthy $(1.7-11.2 \mathrm{pmol} / \mathrm{L}[1])$, this diagnostic algorithm cannot be used when measurements are performed using copeptin US on the KRYPTOR Compact PLUS.

In summary, our results show that the copeptin US KRYPTOR assay performed on the $\mathrm{B} \cdot \mathrm{R} \cdot \mathrm{A} \cdot \mathrm{H} \cdot \mathrm{M} \cdot \mathrm{S}$ KRYPTOR compact PLUS is robust and that the results are repro-

Table 6. Measurement of Copeptin in Different Blanks

\begin{tabular}{|c|c|c|c|}
\hline Sample & Mean Copeptin Concentration (pmol/L) & SD (pmol/L) & $\mathbf{n}$ \\
\hline Diluent (horse serum) run 1 & 1,92 & 0,34 & 22 \\
\hline Diluent (horse serum) run 2 & 1,05 & 0,09 & 4 \\
\hline $5 \%$ Albumin in water & 2,18 & 0,44 & 3 \\
\hline DI patient 1 (serum) & 2,02 & NA & 1 \\
\hline 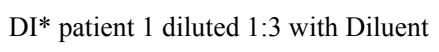 & 0,91 & 0,02 & 4 \\
\hline DI patient 2 (serum) & 1,25 & NA & 1 \\
\hline DI* patient 2 diluted $1: 3$ with Diluent & 1,22 & 0,1 & 4 \\
\hline Pig 1 (plasma) & 0,44 & 0,24 & 3 \\
\hline Pig 2 (plasma) & 1,19 & 0,44 & 3 \\
\hline Pig 3 (plasma) & 1,46 & 0,18 & 3 \\
\hline
\end{tabular}

*DI; Diabetes Insipidus 
ducible, also between independent testing sites, but may lack sufficient analytical sensitivity for some clinical applications.

\section{ACKNOWLEDGEMENTS}

This work was supported by the Swedish Cancer Society $(\mathrm{OH})$, the Swedish Research Council, the Swedish Pain Foundation $(\mathrm{OH})$, the Sahlgrenska University Hospital Research Foundation $(\mathrm{OH})$ and Rigshospitalet Research Council (DT, JPG).

\section{CONFLICT OF INTEREST}

The authors confirm that this article content has no conflicts of interest.

\section{REFERENCES}

[1] Morgenthaler, N.G.; Struck, J.; Alonso, C.; Bergmann, A. Assay for the measurement of copeptin, a stable peptide derived from the precursor of vasopressin. Clin. Chem., 2006, 52(1), 112-9.

[2] Morgenthaler, N.G.; Struck, J.; Jochberger, S.; Dunser, M.W. Copeptin: clinical use of a new biomarker. Trends Endocrinol. Me$t a b,$. 2008, 19(2), 43-9.

[3] Hammarsten, O.; Goetze, J.P. Copeptin: A new peptide in clinical measurement. Klinisk Biokemi i Norden, 2012, 1, 22-7.

[4] Fenske, W.; Quinkler, M.; Lorenz, D.; Zopf, K.; Haagen, U.; Papassotiriou, J.; Pfeiffer, A.F.; Fassnach, M.; Stork, S.; Allolio, B. Copeptin in the differential diagnosis of the polydipsia-polyuria syndrome--revisiting the direct and indirect water deprivation tests. J. Clin. Endocrinol. Metab., 2011, 96(5), 1506-15.

[5] Giannitsis, E.; Kehayova, T.; Vafaie, M.; Katus, H.A. Combined testing of high-sensitivity troponin $t$ and copeptin on presentation at prespecified cutoffs improves rapid rule-out of non-st-segment elevation myocardial infarction. Clin. Chem., 2011, 57(10), 1452-5.

[6] Staub, D.; Morgenthaler, N.G.; Buser, C.; Breidthardt, T.; Potocki, M.; Noveanu, M.; Reichlin, T.; Bergmann, A.; Mueller, C. Use of copeptin in the detection of myocardial ischemia. Clin. Chim. Acta, 2009, 399(1-2), 69-73.

[7] Reichlin, T.; Hochholzer, W.; Stelzig, C.; Laule, K.; Freidank, H.; Morgenthaler, N.G.; Bergmann, A.; Potocki, M.; Noveanu, M.; Breidthardt, T.; Christ, A.; Boldanova, T.; Merki, M.; Schaub, N.; Bingisser, R.; Christ, M.; Mueller, C. Incremental value of copeptin for rapid rule out of acute myocardial infarction. J. Am. Coll. Cardiol., 2009, 54(1), 60-8.

[8] Keller, T.; Tzikas, S.; Zeller, T.; Czyz, E.; Lillpopp, L.; Ojeda, F.M.; Roth, A.; Bickel, C.; Baldus, S.; Sinning, C.R.; Wild, P.S.; Lubos, E.; Peetz, E.; Kunde, J; Hartmann, O.; Bergmann, A.; Post, F.; Lackner, K.J.; Genth-Zotz, S.; Nicaud, V.; Tiret, L; Munzel, T.F.; Blankenberg, S. Copeptin improves early diagnosis of acute myocardial infarction. J. Am. Coll. Cardiol., 2010, 55(19), 2096106.

[9] Meune, C.; Zuily, S.; Wahbi, K.; Claessens, Y.E.; Weber, S.; Chenevier-Gobeaux, C. Combination of copeptin and highsensitivity cardiac troponin T assay in unstable angina and non-STsegment elevation myocardial infarction: a pilot study. Arch. Cardiovasc. Dis., 2011, 104(1), 4-10.

[10] Gu, Y.L.; Voors, A.A.; Zijlstra, F.; Hillege, H.L.; Struck, J.; Masson, S.; Vago, T.; Anker, S.D.; van den Heuvel, A.F.; van Veldhuisen, D.J.; de Smet, B.J. Comparison of the temporal release pattern of copeptin with conventional biomarkers in acute myocardial infarction. Clin. Res. Cardiol., 2011, 100(12), 1069-76.
[11] Narayan, H.; Dhillon, OS.; Quinn, P.A.; Struck, J.; Squire, I.B.; Davies, J.E.; Ng, LL. C-terminal provasopressin (copeptin) as a prognostic marker after acute non-ST elevation myocardial infarction: Leicester Acute Myocardial Infarction Peptide II (LAMP II) study. Clin. Sci. (Lond.), 2011, 121(2), 79-89.

[12] Alehagen, U.; Dahlstrom, U.; Rehfeld, J.F.; Goetze, J.P. Association of copeptin and N-terminal proBNP concentrations with risk of cardiovascular death in older patients with symptoms of heart failure. JAMA, 2011, 305(20), 2088-95.

[13] Voors, A.A.; von Haehling, S.; Anker, S.D.; Hillege, H.L.; Struck, J.; Hartmann, O.; Bergmann, A.; Squire, I.; van Veldhuisen, D.J.; Dickstein, K.; OPTIMAAL Investigators. C-terminal provasopressin (copeptin) is a strong prognostic marker in patients with heart failure after an acute myocardial infarction: results from the OPTIMAAL study. Eur. Heart. J., 2009, 30(10), 1187-94.

[14] Tentzeris, I.; Jarai, R.; Farhan, S.; Perkmann, T.; Schwarz, M.A. Jakl, G.; Wojta, J.; Huber, K. Complementary role of copeptin and high-sensitivity troponin in predicting outcome in patients with stable chronic heart failure. Eur. J. Heart. Fail., 2011, 13(7),726-33.

[15] Stoiser, B.; Mortl, D.; Hulsmann, M.; Berger, R.; Struck, J.; Morgenthaler, N.G.; Bergmann, A.; Pacher, R. Copeptin, a fragment of the vasopressin precursor, as a novel predictor of outcome in heart failure. Eu.r J. Clin. Invest., 2006, 36(11), 771-8.

[16] Maisel, A.; Xue, Y.; Shah, K.; Mueller, C.; Nowak, R.; Peacock, W.F.; Ponikowski, P.; Mockel, M.; Hogan, C.; Wu, A.H.; Richards, M.; Clopton, P.; Filippatos, G.S.; Di Somma, S.; Anand, I.S.; Ng, L.; Daniels, L.B.; Neath, S.X.; Christenson, R.; Potocki, M.; McCord, J.; Terracciano, G.; Kremastinos, D.; Hartmann, O.; von Heahling, S.; Bergmann, A.; Morgenthaler, N.G.; Anker, S.D. Increased 90-Day Mortality in Acute Heart Failure Patients with Elevated Copeptin: Secondary Results from the Biomarkers in Acute Heart Failure (BACH) Study. Circ. Heart. Fail., 2011, 4(5), 61320.

[17] Seligman, R.; Papassotiriou, J.; Morgenthaler, N.G.: Meisner, M.; Teixeira, P.J. Copeptin, a novel prognostic biomarker in ventilatorassociated pneumonia. Crit. Care, 2008, 12(1), R11.

[18] Russell, J.A. Vasopressin and its copilot copeptin in sepsis and septic shock. Crit. Care. Med., 2009, 37(2), 749-50.

[19] Jochberger, S.; Dorler, J.; Luckner, G.; Mayr, V.D.; Wenzel, V.; Ulmer, H.; Morgenthaler, N.G.; Hasibeder, W.R.; Dunser, M.W. The vasopressin and copeptin response to infection, severe sepsis, and septic shock. Crit. Care Med., 2009, 37(2), 476-82.

[20] Urwyler, S.A.; Schuetz, P.; Fluri, F.; Morgenthaler, N.G.; Zweifel, C.; Bergmann, A.; Bingisser, R.; Kappos, L.; Steck, A.; Engelter, S.; Muller, B.; Christ-Crain, M.; Katan, M. Prognostic value of copeptin: one-year outcome in patients with acute stroke. Stroke, 2010, 41(7), 1564-7.

[21] Katan, M.; Fluri, F.; Morgenthaler, N.G.; Schuetz, P.; Zweifel, C.; Bingisser, R.; Muller, M.; Meckel, S.; Gass, A.; Kappos, L.; Steck, A.J.; Engelter, S.T.; Muller, B.; Christ-Crain, M. Copeptin: a novel, independent prognostic marker in patients with ischemic stroke. Ann. Neurol., 2009, 66(6), 799-808.

[22] Kleindienst, A.; Brabant, G.; Morgenthaler, N.G.; Dixit, K.C.; Parsch, H.; Buchfelder, M. Following brain trauma, copeptin, a stable peptide derived from the AVP precusor, does not reflect osmoregulation but correlates with injury severity. Acta Neurochir. Suppl. 2010, 106, 221-4.

[23] Dong, X.Q.; Huang, M.; Yang, S.B.; Yu, W.H.; Zhang, Z.Y. Copeptin is associated with mortality in patients with traumatic brain injury. J. Trauma, 2011, 71(5), 1194-8.

[24] Antonescu-Turcu, A.L.; Tomic, R. C-reactive protein and copeptin: prognostic predictors in chronic obstructive pulmonary disease exacerbations. Curr. Opin. Pulm. Med., 2009, 15(2), 120-5.

[25] Thygesen, K.; Alpert, J.; White, H.; Jaffe, A.; Apple, F.; Galvani, M. Universal definition of myocardial infarction. Circulation, 2007, 116(22), 2634-53.

(C) Terzic et al.; Licensee Bentham Open.

This is an open access article licensed under the terms of the Creative Commons Attribution Non-Commercial License (http://creativecommons.org/licenses/by-nc/3.0/) which permits unrestricted, non-commercial use, distribution and reproduction in any medium, provided the work is properly cited. 